\title{
Berwirausaha Trendy Melalui Digitalisasi Fotocopy
}

\author{
Dina Wulandari*1, Hendri Hermawan Adinugraha², M. Aris Safii ${ }^{3}$, Shokhibul Mutaqin, \\ Rizky Andrean ${ }^{5}$ \\ 1,2,3,4,5Fakultas Ekonomi dan Bisnis, Institut Agama Islam Negeri Pekalongan \\ *e-mail: dinawulandari42@gmail.com¹, hendri.hermawan@iainpekalongan.ac.id², \\ arissafii@iainpekalongan.ac.id ${ }^{3}$, shokhibulmutaqin@gmail.com ${ }^{4}$, \\ rizkyandrean@mhs.iainpekalongan.ac.id ${ }^{5}$
}

\begin{abstract}
Indonesia needs 4 (four) million new entrepreneurs to encourage the strengthening of the economic structure. Currently, the number of entrepreneurs is still around 3.10\% of the total population or around 250 million people. Entrepreneurship is a creative and innovative ability that always regulates business actors to see opportunities and is open to input from others so as to be able to provide positive changes that can bring positive changes to the business we live in. Entrepreneurs have a tendency to continue to innovate and regulate new technology to win market competition and increase the nation's competitiveness. In addition, it also creates a lot of jobs so that the unemployed are unemployed. The standard is that at least $2 \%$ of the population must work as entrepreneurs. With a population of 250 million, Indonesia must have at least 5 million entrepreneurs. The purpose of implementing this service through practical work experience from home is to increase knowledge and understanding for business owners about good and true entrepreneurship. The method of implementing this activity uses an educational approach, on-site service and business assistance. Meanwhile, the output that resulted from this service activity was scientific publications in ISSN journals.
\end{abstract}

Keywords: digitalization, population, entrepreneurship

\begin{abstract}
Abstrak
Indonesia membutuhkan 4 (empat) juta wirausahawan baru untuk mendorong penguatan struktur ekonomi. Saat ini jumlah wirausahawan masih sekitar 3,10\% dari total populasi penduduk atau sekitar 250 juta jiwa. Wirausaha merupakan kemampuan kreatif dan inovatif yang selalu mengajarkan pelaku usahanya untuk jeli melihat peluang dan terbuka untuk masukan dari orang lain sehingga mampu memberikan perubahan positif yang mampu membawa perubahan positif bagi usaha yang kita jalani. Pengusaha memiliki kecenderungan untuk terus berinovasi dan memunculkan teknologi baru untuk memenangkan persaingan pasar dan meningkatkan daya saing bangsa. Selain itu, juga menciptakan banyak lapangan kerja sehingga angka pengangguran dapat ditekan. Patokannya adalah minimal 2\% dari jumlah penduduknya harus berprofesi sebagai wirausaha. Dengan jumlah penduduk Negara kita adalah 250 juta jiwa, maka Indonesia harus memiliki setidaknya 5 juta wirausaha. Tujuan dari pelaksanaan pengabdian melalui praktik pengalaman kerja dari rumah ini adalah menambah pengetahuan dan pemahaman bagi pemilik usaha tentang kewirausahaan yang baik dan benar. Metode pelaksanaan kegiatan ini menggunakan pendekatan edukasi, pengabdian ditempat dan pendampingan usaha. Sedangkan luaran yang dihasilkan dari kegiatan pengabdian ini adalah publikasi ilmiah pada jurnal ber-ISSN.
\end{abstract}

Kata kunci: digitalisasi, penduduk, wirausaha

\section{PENDAHULUAN}

Bisnis dan perdagangan di kalangan umat Islam bukanlah hal baru. Jika menyoroti perdaganga sejarah islam, sejarahnya dimulai oleh dua putra nabi Adam yaitu Habil dan Qabil yang telah mempelopori bidang kewirausahaan. Habil merintis usaha peternakan dan Qabil merintis usaha pertanian (Nor, 2012).

Nabi sendiri terlibat langsung dalam bisnis, bahkan sebelum diangkat menjadi rasul. Sejak usia 12 tahun tercatat sejarah yang kerap mengikuti rombongan pamannya Abu Thalib gulung tikar di Sham (Nizho\& Mohd, 2008). Beliau menjadi salah satu pedagang yang memasarkan barang- barang milik Khadijah binti Khuwaiid (R.A) ke negara-negara seperti Suriah dan Yaman. 
Wirausaha adalah bagian dari komunitas yang diterima sebagai hal penting dalam pengembangan suatu komunitas. Mereka memainkan peran penting dalam menyelesaikan masalah yang dihadapi oleh masyarakat dengan menemukan berbagai alternative untuk mengatasi masalah ini. Maka tidak heran area ini diidentifikasikan sebagai katalis potensial untuk pengembangan ekonimi nasional. Selain itu, mereka sangat dianjurkan untuk menjadikan daerah Muslim ini supaya meningkatkan kehidupan mereka secara tidak langsung menyediakan lapangan kerja sebagai kehidupan mereka dan secara langsung menyediakan lapangan kerja bagi orang lain sesuai dengan tradisi Nabi yang disebutkan sebelumya.

Negara Indonesia sedikitnya membutuhkan 4 (empat) juta wirausahawan untuk mendorong penguatan struktur ekonomi (Raharjo \& Trisyuliono, 2019). Saat ini sampai dengan tahun 2019, rasio wirausahawan di dalam negeri masih sekitar 3,1\% dari total populasi penduduk sekitar 8,06\% juta orang (Siregar, 2019). Data menurut Menteri Perindustrian bahwa meskipun rasio tersebut sudah melampaui standar internasional, yaitu $2 \%$, akan tetapi Indonesia masih sangat perlu menggenjot lagi untuk mengejar capaian negara tetangga. Sebagai contohnya, Malaysia berada di level 6\% dan Singapura sudah mencapai 7\% dari total penduduknya (Walter, 2019).

Wirausaha sangat banyak diminati oleh semua kalangan. Karena wirausaha mempunyai kebebasan untuk bekarya. Wirausaha sendiri merupakan salah satu pendukung perekonomian. Maju mundurnya perekonomian suatu Negara bisa dilihat dari kualitas dan kuantitas dari wirausaha yang dilakukan oleh masyarakat di Negara tersebut. Wirausaha sangat diminati karena wirausaha tidak perlu mengandalkan orang lain, tidak terikat dengan orang lain dan mampu menciptakan lapangan pekerjaan(Ranto, 2007:18)

Wirausaha harus dijalani dengan baik agar bisa menjadikan peluang bisnis yang baik pula. Namun, wirausaha tak selalu berjalan mulus seperti yang dibayangkan orang-orang diluar sana. Wirausaha sendiri menunjuk pada semangat, sikap dan perilaku sebagai teladan dalam keberanian mengambil resiko yang telah diperhitungkan berdasarkan atas kemauan dan kemampuan sendiri.

\subsection{Landasan Teori}

Pemasaran adalah kegiatan pokok yang dilakukan dalam untuk mempertahankan usaha yang kita jalankan. Pemasaran sendiri bertujuan untuk mengembangkan usaha, memperbanyak pelanggan dan menambah laba atau penghasilan. Ahli pemasaran mendefinisikan dari beberapa arti pemasaran yang dikemukakan oleh para ahli lainnya. Banyak dari definisi pemasaran yang dikemukakan sebelumnya. Dan dari definisi tersebut banyak kesamaan. Salah satunya yaitu memenuhi dan melayani permintaan sesuai kebutuhan konsumen dengan barang dan jasa yang dibutuhkan dan diinginkan (David, 2004:34).

Ada banyak persaingan yang timbul saat ini harus disikapi dengan bijak oleh seorang pengusaha. Sebagai reaksi lingkungan, serorang wirausaha perlu berinteraksi dengan lingkungan agar bisa memahami lingkungan baru yang akan mempengaruhi kehidupan mereka. Reaksi tersebut biasa dikenal dengan istilah perilaku, yaitu reaksi dalam menanggapi suatu peristiwa. Dalam hal ini, perilaku wirausaha terjadi karena adanya dorongan kebutuhan untuk mempertahankan kelangsungan usaha. Dalam suatu usaha sangatlah diperlukan perilaku yang didalamnya mengandung kompetensi yang dibutuhkan untuk keberhasilan usaha dengan kemampuan memanfaatkan peluang usaha dan kesanggupan mengambil resiko demi kelangsungan hidup usaha.

Untuk dapat merebut pasar dalam persaingan yang ketat dengan pelaku usaha lain, maka setiap pelaku usaha harus menyusun rencana usaha dengan tepat dan terlihat berbeda dari pelaku usaha lain, terutama dalam bidang pemasaran. Salah satu faktor yang mendukung keberhasilan dalam suatu usaha adalah strategi pemasaran. Pemasaran yang biasanya dihadapkan pada masalah harga, produk,tempat dan promosi, maka dari itu kita sebagai 
wirausaha harus paham betul dan tahu bagaimana cara menerapkannya agar tujuan yang diinginkan dapat tercapai dengan baik.

Persaingan diantara pengusaha yang ketat, menuntut pengusaha memiliki pemasaran yang baik agar tetap bisa bertahan. Banyaknya pengusaha dalam satu tempat, persaingan harga yang semakin ketat, dan fasilitas yang diberikan, hal itu sangat berpengaruh terhadap pendapatan pengusaha yang tepat dengan tujuan untuk memenangkan persaingan. Cara untuk memenangkan sebuah persaingan salah satunya adalah dengan melakukan penataan pemasaran yang baik seperti dengan menyediakan, menetapkan dan memberikan harga produk yang dapat memuaskan kebutuhan dan keinginan target pasar yang dituju sehingga dapat menarik konsumen dan bahkan dapat meningkatkan jumlah pelanggan.

Berdasarkan uraian latar belakang diatas, maka kegiatan pengabdian melalui praktik pengalaman kerja dari rumah ini adalah menambah pengetahuan dan pemahaman bagi pemilik usaha tentang kewirausahaan yang baik dan benar. Selain itu, pengabdian ini juga untuk mendukung program pemerintah untuk meningkatkan jumlah wirausahawan di Indonesia.

\subsection{Analisis Situasi}

Media Digital Print Pekalongan didirikan oleh Bapak Abidin sejak tahun 2014 dan kemudian dilanjutkan oleh putranya Helmi Abidin pada tahun 2017 sampai sekarang. Lokasi usaha terletak di Kota Pekalongan. Tepatnya di jl. Tunas Raya (Belakang UNIKAL) kecamatan Pekalongan Barat, Kota Pekalongan. Lokasi yang sangat berdekatan dengan Universitas Pekalongan sangat strategis dan mudah dijangkau. Usaha percetakan yang dihasilkan yaitu fotocopy, printcopy, penjilidan, print warna, cetak brosur, undangan, sertifikat, foto, stiker dan sebagainya.

Berdasarkan hasil observasi yang dilakukan peneliti, didapatkan hasil sebagai berikut:

1. Peralatan yang digunakann sudah cukup baik, namun terkadang terdapat kendala seperti kerusakan kecil yang terkadang menghambat kerja namun tidak bisa diselesaikan sendiri dan jika memanggil teknisi akan menunggu terlalu lama dan bisa saja menghilangkan pelanggan

2. Keterbatasan pada modal dan penghasilan yang menghambat menambah jumlah pegawai, sehingga pekerjaan kurang terkendali disaat kondisi toko ramai

3. Pendapatan kotor perbulannya adalah Rp. 6.000.000 sampai Rp. 9.000.000.

Bahan baku yang digunakan yaitu kertas fotocopy, dan penjilidan. Bahan baaku tersebut dapat didapatkan di toko alat tulis dan toko kertas. Sedangkan peralatan yang digunakan adalah komputer, mesin fotocopy, printer, scanner, dan banyak peralatan lain.

Tabel 1. Spesifikasi peralatan

\begin{tabular}{clcc}
\hline No & Jenis Peralatan & Jumlah & Keterangan \\
\hline 1 & Komputer & 11 & Baik \\
2 & Mesin Fotocopy & 3 & Baik \\
3 & Printer warna & 7 & \\
4 & Mesin Laminating & 1 & Baik \\
5 & Mesin Pemotong Kertas & 3 & Baik \\
& Perkakas Lain (Boplpoin, Cutter, & & \\
6 & Penggaris Sebagai Pendukung Kerja) & Beberapa & Baik \\
\hline
\end{tabular}


Garis besar proses produksi yang dilakukan di Toko Media Digital Print yaitu:

1. Pelanggan datang ke toko dengan membawa file yang akan di print atau dicetak. Juka pelanggan belum membawa, kami memberikan akses bagi pelanggan untuk mecari atau membuat terlebih dahulu yang mereka inginkan karena toko menyediakan banyak unit komputer yang bisa bebas dipakai oleh pelanggan.

2. Jika pelanggan kurang paham, maka akan diarahkan oleh penjaga toko agar bisa sesuai seperti yang pelanggan inginkan.

3. Setelah selesai, maka dapat dicetak sesuai yang diminta pelanggan seperti print warna atau akan diprint copy saja.

4. Hasil cetakan selesai dibuat, kemudian dicek kembali oleh pelanggan dan pelanggan membayar dan transaksi selesai.

\subsection{Permasalahan}

Berdasarkan permasalahan yang terjadi pada Toko Media Digital Print, maka terbagi menjadi beberapa aspek yaitu aspek produksi, produk, pemasaran (Nisak, 2013), dan keuangan. Dan untuk mempermudah dalam menentukan permasalahan yang ada di Toko Media Digital Print tersebut maka dapat dilihat pada Tabel.2

Tabel 2. Permasalahan

\begin{tabular}{|c|c|c|}
\hline No & Dimensi Bisnis & Permasalahan \\
\hline 1 & Aspek produksi & $\begin{array}{l}\text { - Sering terjadi kerusakan kecil pada mesin, namun tidak } \\
\text { bisa diselesaikan sendiri dan jika memanggil teknisi } \\
\text { akan membutuhkan waktu yang lama }\end{array}$ \\
\hline 2 & Aspek produk & $\begin{array}{l}\text { - Hasil cetakan terkadang kurang pekat, dikarenakan } \\
\text { aturan mesin yang berubah- ubah sendiri } \\
\text { - Minim pengetahuan desain, dan lebih sering menolak } \\
\text { order pembuatan desain }\end{array}$ \\
\hline 3 & Aspek pemasaran & $\begin{array}{l}\text { - Tidak ada media pemasaran } \\
\text { - Dirasa, kurang efeksif jika dipasarkan melalui sosial } \\
\text { media }\end{array}$ \\
\hline 4 & Aspek keuangan & $\begin{array}{l}\text { - Hasil dari toko jadikan satu } \\
\text { - } \text { Kurangnya pembukuan yang jelas dan dapat dipahami } \\
\text { - Pencampuran antara kebutuhan toko dengan } \\
\text { kebutuhan pribadi oleh pemilik }\end{array}$ \\
\hline
\end{tabular}

\section{METODE}

Solusi yang ditawarkan merupakan target keberhasilan yang dicapai oleh tim pengabdian dengan Toko Media Digital Print. Adapun target keberhasilan yang dicapai yaitu:

1. Pemilik atau pengelola toko dapat mempelajari dan memahami cara menghadapi kendala- kendala kecil pada mesin

2. Dapat dilakukan pengecekan setting pada mesin setiap hari, agar jika terjadi perubahan pada setting diketahui oleh pengelola. Sehingga bisa melakukan setting ulang agar pelanggan tidak kecewa

3. Pengelola dapat belajar desain dari youtube dan platform lain agar bisa menerima order desain dari pelanggan

4. Pengelola dapat memulai memasarkan produk cetak dan editing dalam sosial media seperti cetak foto agar orang diluar sana mengetahui apa saja yang dapat dilakukan di Toko Media Digital Print

5. Pengelola harus lebih hati- hati dalam mengelola keuangan dan segera membuat pembukuan yang jelas agar pengelola tahu berapa besar laba bersih yang didapatkannya. 


\section{HASIL DAN PEMBAHASAN}

\subsection{Hasil}

Hasil yang dicapai dari kegiatan pengabdian sesuai dengan solusi yang ditawarkan yaitu:

1. Pembelajaran kepada pengelola dalam menghadapi kendala- kendala kecil yang terjadi pada mesin

Permasalahan yang dihadapi oleh Toko Media Digital Print adalah kurangnya pengetahuan pengelola tentang bagaimana cara menghadapi kendala- kendala kecil yang terjadi pada mesin agar pekerjaan bisa tetap dilakukan dan tidak menghambat pekerjaan yang lainnya. Kemudian pengelola bisa belajar melalui Youtube dan bisa menyelesaikan permasalahan tersebut sendiri tanpa menunggu teknisi yang datangnya terlalu lama.

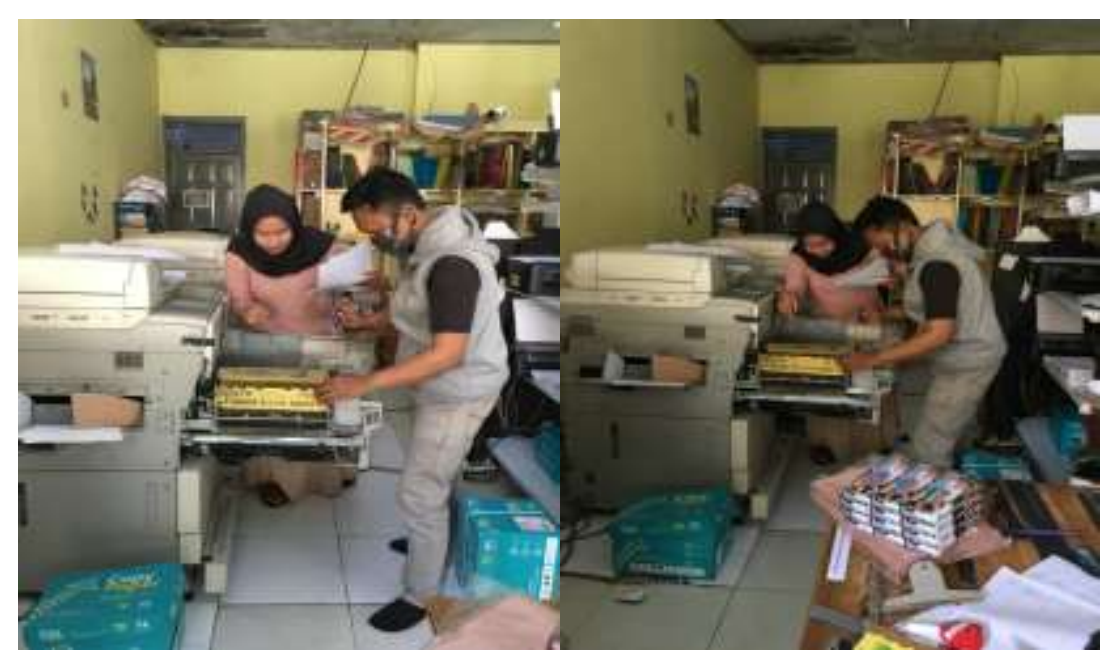

Gambar 1. Pemahaman kendala pada mesin

2. Pengecekan setting pada mesin yang harus dilakukan setiap hari

Pengecekan mesin tersebut bertujuan untuk meminimalisir kekecewaan pelanggan yang dikarenakan oleh hasil cetakan yang kurang jelas ataupun kurang tebal. Sehingga, pengelola bisa melakukan cek tersebut setiap hari.

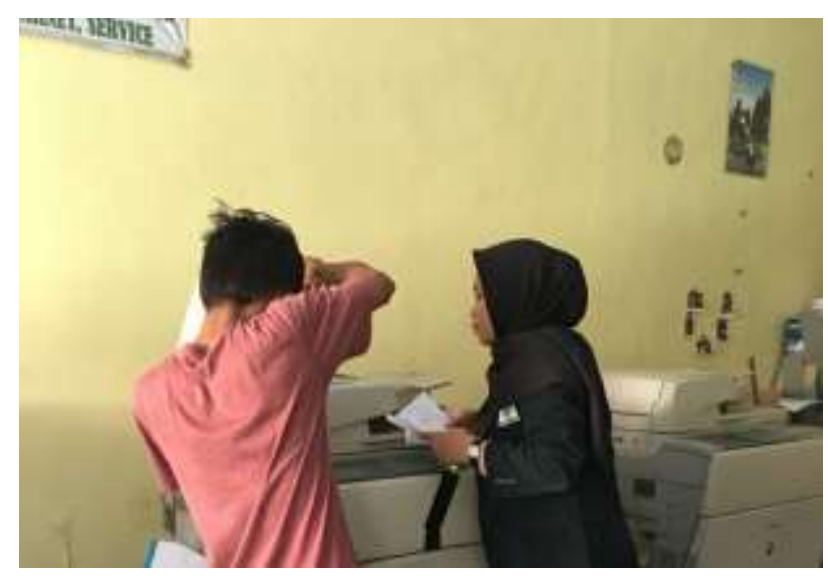

Gambar 2. Pengecekan mesin

3. Pembelajaran desain kepada pengelola

Fasilitas yang diberikan sebelumnya adalah pemberian fasilitas editing file yang akan dicetak, seperti editing skripsi ataupun file lain yang dirasa pelanggan tersebut kurang sempurna dan itu sudah terlaksana sejak lama. Namun karena Toko Media Digital Print 
juga menerima print stiker, terkadang ada beberapa pelanggan yang meminta dibuatkan desain sesuai yang mereka inginkan. Namun, pada kenyataannya pengelola kurang menguasai ilmu desain pada CorelDraw ataupun aplikasi desain lainnya. Maka dari itu, dalam proses pengabdian ini kami memberikan pembelajaran pada pengelola dalam penguasaan desain agar dapat menerima order desain yang diinginkan pelanggan dan pelanggan tidak kecewa.
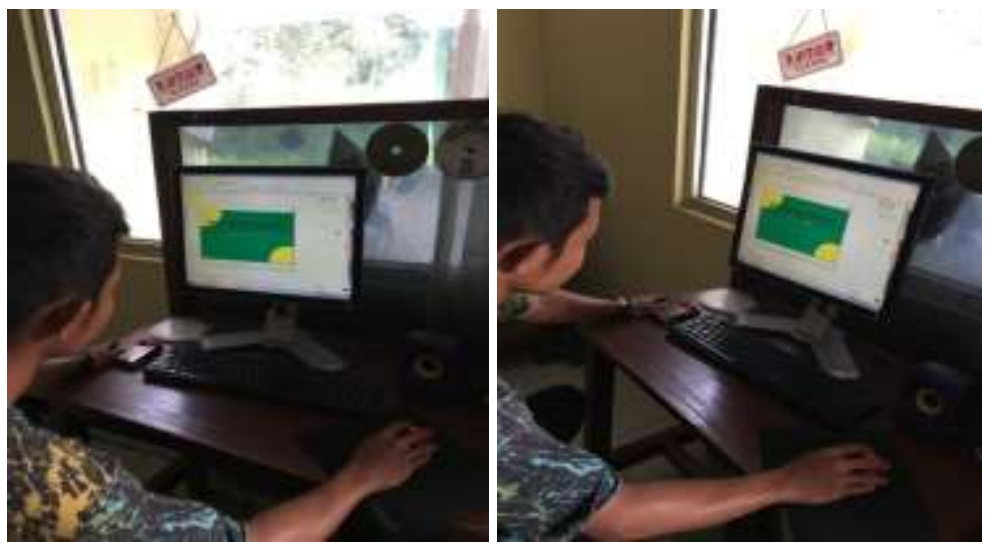

Gambar 3. Pembelajaran Desain

4. Pemasaran dengan media online

Tim pengabdian memberikan pembelajaran tentang promosi dan pemasaran melalui media sosial sehingga masyarakat luas dapat melihat dan mengetahui keberadaan dan fasilitas yang diberikan oleh Toko Media Digital Print. Dan sampai saat ini telah dilaksanakan oleh pengelola yaitu pemasaran melalui media sosial di akun Instagram dan Whatsapp milik pengelola dan banyak respon baik dari masyarakat seperti banyak mahasiswa yang menghubungi pengelola untuk editing skripsi, pembuatan desain rumah makan, dan yang paling banyak adalah cetak foto plaroid.

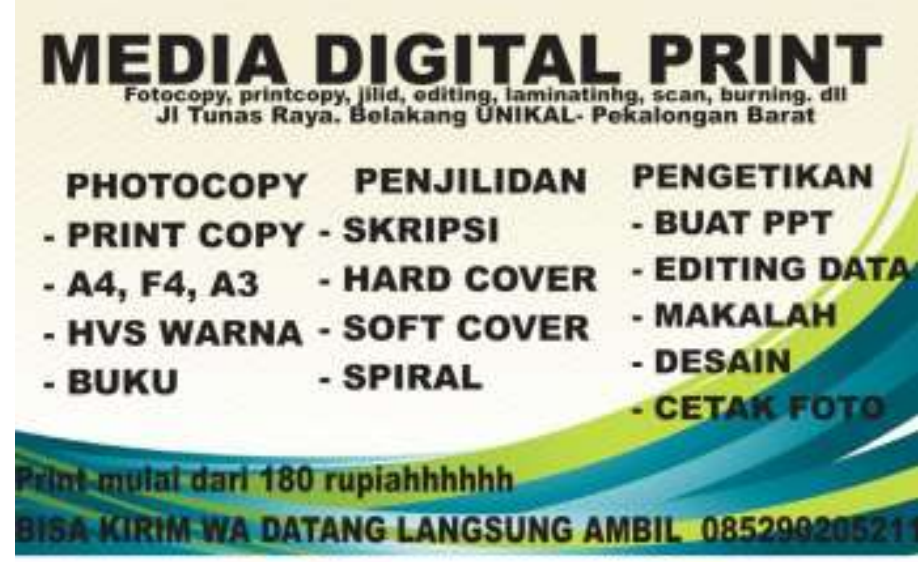

Gambar 4. Brosur yang di unggah di sosial media sebagai pemasaran

5. Pembuatan catatan keuangan

Catatan keuangan ini dimaksudkan agar pengelola dapat mengelola keuangan dengan bijak dan dapat membedakan antara penghasilan dan uang balik modal sehingga tidak terjadi yang tidak diharapkan. Maka dari itu saran dari tim pengabdian adalah memberikan gaji kepada diri sendiri dikarenakan pengelola merupakan pemilik dari Toko Media Digital Print yang kemudian dapat memisahkan sisa dari penghasilan kemudian dikurangi sebagai gaji dan modal kemudian sisanya disimpan sebagai asset. 


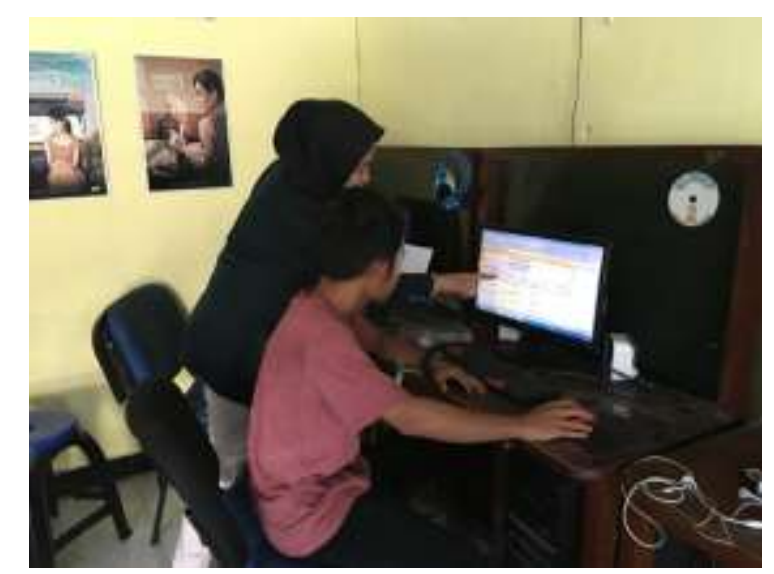

Gambar 5. Pembuatan laporan keuangan

\subsection{Rencana Tahap Selanjutnya}

Setelah kegiatan sosialisasi, pengabdian dan pelatihan dilaksanakan, selanjutnya yang harus dilakukan adalah

1. Tim pengabdian melakukan pemantauan kegiatan yang dilakukan oleh pengelola Toko Media Digital Print

2. Mengevaluasi kegiatan yang sudah dilakukan oleh tim pengabdian

3. Melakukan pendampingan pemasaran melalui media sosial yang sudah disarankan tim sebelumnya dan memberikan pendampingan manajemen keuangan.

\section{KESIMPULAN}

Berdasarkan hasil dari kegiatan sosialisasi, pengabdian, pelatihan kepada pengelola Toko Media Digital Print, maka dapat disimpulkan yaitu:

1. Tingkat partisipasi dan rasa ingin tahu terhadap perembangan usaha yang dilakukan oleh pengelola Toko Media Digital Print memberikan dampak positif pada saat melakukan pelatihan pembelajaran setting mesin pada kendala mesin berskala kecil, pembelajaran desain, pembelajaran pemasaran di media sosial, dan pembelajaran manajemen keuangan.

2. Pelaksanaan kegiatan pengabdian menghasilkan luaran- luaran yang diharapkan oleh pengelola Toko Media Digital Print yaitu meningkatkan pendapatan dari usaha yang dijalankan.

\section{DAFTAR PUSTAKA}

Basuki Ranto. (2007). kewirausahaan, (Jakarta: Grafindo Persada,2007)

Desnelita, Y., Gustientiedina, Susanti, W., Nasien, D., \& Putri, R. N. (2019). Pkms Pelatihan Desain Grafis Menuju Wirausaha Bagi Pemuda Rt.03 Rw.04 Kelurahan Umban Sari. DINAMISIA:Jurnal Pengabdian Kepada Masyarakat

Hyperlink "https://journal.unilak.ac.id/index.php/dinamisia/article/view/3662/1967" https://journal.unilak.ac.id/index.php/dinamisia/article/view/3662/1967

Fred R.David. (2004). Manajemen Strategi, Edisi Bahasa Indonesia, (Jakarta: PT Indeks Kelompok Gramedia, 2004)

Nisak, Z. (2013). Analisis SWOT untuk menentukan strategi kompetitif. Jurnal Ekbis, 2.

Nizho\& Mohd, S. (2008). An Islamic approach to quality and productivity Quality management from Islamic perpective. Kuala Lumpur: Schlar Mind Publising. 
Nor, H. (2012). Ethics and value in Busines for Muslim. Malaysia: Universiti Kebangsaan Malaysia.

Raharjo, D. B., \& Trisyuliono, M. (2019). Menperin: Indonesia Butuh 4 Juta Wirausaha Baru untuk Penguatan Ekonomi.

https://www.suara.com/bisnis/2019/03/26/175629/menperin-indonesa-butuh-4 jutawirausaha-baru-untuk-penguatan-ekonomi (diakses tanggal 6 juli 2020 pukul $14.00 \mathrm{WIB}$ )

Siregar, T. (2019,). Jumlah Wirausaha di Indonesia Tembus 8 Juta Jiwa.

Hyperlink "https://rri.co.id/ekonomi/651422/jumlah-wirausaha-di-indonesia-tembus-8juta-jiwa" https://rri.co.id/ekonomi/651422/jumlah-wirausaha-di-indonesia-tembus-8juta-jiwa (diakses tanggal 6 juli 2020 pukul 14.10WIB)

Walter. (2019). Jumlah Pengusaha di Indonesia Meningkat,. Hyperlink "https://koinworks.com/blog/jumlah-pengusaha-di-indonesia-meningkat/" https://koinworks.com/blog/jumlah-pengusaha-di-indonesia-meningkat/ (diakses tanggal 6 juli 2020 pukul 14.20 WIB) 